\title{
VIRTUAL LABORATORY OF ELECTRICITY CONCEPT TO IMPROVE PROSPECTIVE PHYSICS TEACHERS' CREATIVITY
}

\author{
Gunawan $^{1 *}$, A. Harjono1, H. Sahidu ${ }^{1}$, L. Herayanti ${ }^{2}$ \\ ${ }^{1}$ Physics Education Study Program, Faculty of Teacher Training and Education, \\ Universitas Mataram, Indonesia \\ ${ }^{2}$ Physics Education Study Program, Faculty of Mathematics and Science Education, \\ Institut Keguruan dan IImu Pendidikan Mataram, Indonesia
}

Received: 16 March 2017. Accepted: 28 Mey 2017. Published: 1 July 2017

\begin{abstract}
A virtual laboratory for electrical materials has been developed in this study. The virtual laboratory was developed as an alternative laboratory due to the limited equipment of physics experiments and simultaneously assisting students in visualizing abstract concepts in physics. This article discusses the results of testing on the effects of virtual laboratories on improving the creativity of prospective physics teachers. Measurable creativity includes verbal and figural creativity. The model testing process uses the quasi-experimental method. The participant of this research is prospective physics teachers in Faculty of Teacher Training and Education, University of Mataram. The research instrument used in the form of tests of verbal and figural creativity related to the electrical material being studied. The results showed that there is a difference in the improvement of prospective physics teachers' creativity after learning in both groups. In general, the increase in creativity in the experimental group is higher than the control group. The increase in verbal and figural creativity of the two groups also differed significantly. In both groups, the increase of verbal creativity is higher than that of figural creativity. This suggested that the developed virtual lab model proved to enhance the creativity of prospective physics teachers.
\end{abstract}

\begin{abstract}
ABSTRAK
Dalam penelitian ini telah dikembangkan laboratorium virtual untuk materi listrik. Laboratorium virtual dikembangkan sebagai alternatif terbatasnya peralatan eksperimen fisika dan membantu visualisasi pada berbagai konsep abstrak dalam fisika. Artikel ini membahas hasil pengujian pengaruh laboratorium virtual terhadap peningkatan kreativitas calon guru fisika. Kreativitas yang diukur meliputi kreativitas verbal dan figural. Pengujian model menggunakan metode kuasi eksperimen. Subjek penelitian ini adalah mahasiswa calon guru fisika di FKIP Universitas Mataram. Instrumen penelitian yang digunakan berupa tes kreativitas verbal dan figural yang terkait dengan materi listrik yang dipelajari. Hasil penelitian menunjukkan adanya perbedaan peningkatan kreativitas calon guru fisika setelah pembelajaran pada kedua kelas. Secara umum, peningkatan kreativitas pada kelas eksperimen lebih tinggi dibandingkan kelas kontrol. Peningkatan kreativitas verbal maupun figural pada kedua kelas juga berbeda secara signifikan. Pada kedua kelas, peningkatan kreativitas verbal lebih tinggi dibandingkan kreativitas figural. Hal ini menunjukkan bahwa model laboratorium virtual yang dikembangkan terbukti dapat meningkatkan kreativitas calon guru fisika.
\end{abstract}

(C) 2017 Jurusan Fisika FMIPA UNNES Semarang

Keywords: Electricity concept; Prospective teachers' creativity; Virtual laboratory

\section{INTRODUCTION}

Laboratory activities are important component in physics learning. Through laboratory activities aspects of processes, products,

*Correspondence Address:

JI. Majapahit No. 62 Mataram 83125, Nusa Tenggara Barat E-mail: gunawan@unram.ac.id and scientific attitudes can be improved. In the teaching of physics it have an important role, among others, as a vehicle for: (1) developing basic skills of observing or measuring and other process skills such as taking notes, creating tables, graphs, analyzing data, drawing Conclusion, communication, and teamworking; (2) proving the concept or laws of nature so as 
to further clarify the concept which has been discussed previously; (3) developing thinking skills through problem-solving processes in order to help students find their own concepts. It means that the laboratory has been used as a vehicle for learning how to learn (Wiyanto, 2008).

In experimental activities in the laboratory, students can also develop academic and social skills. Through this activity students can improve the mastery of concepts, develop learning skills, conduct their own experiments, and develop a variety of scientific skills. From a social point of view, learners will be accustomed to appreciate the opinions of others, learn to communicate ideas, and work together on teams.

One of the factors that affect the success of laboratory activities is the availability of resources, including materials and equipment, space and furniture, laboratory staff, and technicians. The availability of adequate resources will obviously support the implementation of laboratory activities, on the contrary the limitations of tools and materials will lead to the ineffectiveness of laboratory experiments.

The result of observation of availability of supporting facilities and laboratory activities in some teacher education in West Nusa Tenggara shows that physics experiment activity can not be done due to inadequate equipment. Generally available tools are limited in number compared to the ratio of students who will use them, while some advanced experimental support tools are not available at all. This will certainly have implications for the learning process. In the framework of expansion, equity of quality and access to education, it is necessary to consider solutions that enable laboratory activities to be carried out to support the physical learning process as it should be implemented.

The development of information technology provides an opportunity to build and use computer animation for learning oriented to microscopic representations. This fact is then the starting point of the emergence of new innovations in physics learning. One of them is the use of computer technology, both in the process of learning and experimental activities virtually. A computer simulation that allows important functions of laboratory experiments to be performed on a computer is called a virtual laboratory. In general, virtual laboratories are intended to transfer knowledge both conceptually and procedurally. In the implementation, it is necessary to give initial knowledge to the students about how the experiment should be done.

Chen, Song \& Zhang (2010) define a virtual laboratory as software for simulating a laboratory environment. Ciepiela et al. (2010) has stated that the key concept of a virtual laboratory is an experiment. Experiments are processes that combine data with a series of activities to get experimental results. Virtual experiments are complex workflows, execution of recurring instructions from programs installed on the computer.

Under the definition, virtual labs are not considered as substitutes or competitors for real laboratories, but rather as extensions to new opportunities that are unrealized in real and affordable laboratories. One of the principles of defining virtual labs is that virtual laboratories are not defined as learning units but rather learning space for virtual experiments. It is important to remind that lecturers still have to explain the learning objectives to the students.

Digital computers are an important tool for investigation in scientific research. Computer simulations are not intended to replace real laboratory equipment. All students in the laboratory should have the opportunity to gain confidence in their ability to solve problems and explore with mechanical, thermal, optical and electrical systems. Using a virtual laboratory, students have the opportunity to apply scientific methods with complete accuracy for every phenomenon they face (Harms, 2000).

The virtual laboratory must provide sufficient discretion for individual experiments or experiments beyond the limits set by the curriculum. The use of virtual labs in various learning models has been able to improve the mastery of physics concepts. Nisrina et al. (2016) found that the use of virtual laboratories in cooperative learning models can improve the mastery of physics concepts. Other researchers have also tried to use virtual laboratories in physics learning with different learning models, for example Sugiana et al. (2016) using laboratories in generative learning models on impulse momentum materials; Sari et al. (2016) who use virtual labs in discovery learning models in dynamic electrical materials; and Kusdiastuti et al. (2016) who use it in an inquiry model on optical materials. These studies have proved to have a significant effect on the use of virtual laboratories to increase the mastery of students' physics concepts.

Virtual lab-assisted learning is expected 
to enhance the creativity of prospective physics teachers. Mishra (2012) explains that in the last few decades, digital technology has contributed to the development of creativity. According to Harding (2010), creative action is essential for the advancement of civil society. Thus, teaching students to think creatively is very useful for them to be skilled and tough in the future. Rawat et al. (2012) had stated that creativity is the main goal of education worldwide.

It is important to equip physics teacher candidates to think creatively so that they can be creative teachers, teach and equip creativity to the students. Creativity is needed to enable them to act creatively and excel in global competition. According to Wu et al. (2014) creative talent is the foundation of a nation's competitive advantage and university is the main core for fostering such creative talents.

Jackson (2006) stated that creativity is a fundamental characteristic of human being which is the center of prosperity, productivity and prosperity of a nation. However, the existence of this creative character in higher education seems almost unacknowledged. Creativity arises spontaneously through the relationship and interaction of lecturers with their students in very specific and challenging situations. Whereas Jackson et al. (2012) defines creativity as a mental process involving the development of new ideas or concepts, or new relationships with existing ideas or concepts. From a scientific point of view, the product of creative thinking is usually considered to have originality and conformity. Creativity is unique among scientific phenomena that can not be defined with only one definition. Aqda, Hamidi \& Rahimi (2011) considers creativity as one of the extraordinary characteristics of human beings. The development of creative strategies such as brainstorming and problem solving whose general purpose is to provide the environment in generating ideas. Creativity is an innate talent and attaches to every human being

Most researchers who cultivate about creativity generally recognize that creativity is not synonymous with intelligence (Runco, 2004). However, creativity demands an extraordinary resource of knowledge and domain relevant to skills (Mumford et al., 2009). There is a general consensus of creativity researchers who claim that creativity is a complex process in which interactive relationships lie in four dimensions: creative people, cognitive processes of creativity, product of creative performance, and social and cultural contexts (Batey \& Furnham, 2006;
Zimmerman, 2009).

Creativity is a complex process of relationships between people, processes, products, and the socio-cultural context relevant to the knowledge domain. People who are not creative in the general sense, sometimes they are creative in certain domains such as visual arts. Creativity can be developed through learning. In the concept of creativity should be considered that all learners have the ability to be creative (Zimmerman, 2010).

Rawat et al. (2012) stated that a creative person is a person who is able to judge accurately in putting facts into ideas, selecting and elaborating ideas. A child cannot learn this art unless it is taught, and is allowed to go through the process as it should. In his research, Garaigordobil (2006) gave treatment to stimulate the four types of creativity: verbal, graphicfigural, constructive, and dramatic creativity. Other researchers O'Reilly et al. (2001) described creativity in verbal and figural groups. Verbal creativity can be grouped in indicators of originality, flexibility, fluency while figural creativity can be grouped in originality, elaboration. On the other hand Preckel et al. (2006) states that creativity can also be grouped into verbal, figural, and numerical creativity.

One's creativity cannot develop automatically by itself, but requires the stimulation of the environment. To develop the creative potential of an individual, an external driving force is required in a situation that supports the potential within the individual. Kandiko (2012) explains that in order to support and enhance creativity, it can start by exploring how the relationship between sciences that has many features such as creativity to be further understood and taught in higher education. In perspective, creativity can be developed; learning and the results reflect something new and valuable. However, most creative works have a meaning to be directly involved. This indicates that a change in the teacher education pattern is required. This is useful for helping prospective teachers to have an understanding of (1) what creativity is required; (2) how to recognize student work; (3) the types of tasks that can foster creativity; (4) creative pedagogy (Wyse \& Ferrari, 2015).

The importance of providing creativity for prospective teachers raises new innovations by each teacher to prepare future and creative teachers who are able to compete. The development of a virtual lab model is one of the limited alternatives of physics experimental equipment that can be used to equip the creativity of 
physics teacher candidates. Creativity can be developed from exercises or lessons created by lecturers together with students in a creative learning environment. Bricken \& Byrne (1993) revealed that virtual media is a very interesting creative environment to teach and learn.

Stages in learning by using a virtual laboratory encourage the increase creativity. The introduction stage serves to introduce the virtual laboratory, functionality features, to its use. The activity continued with brainstorming through discussions related to conceptual design between lecturers and students. This discussion activity can improve students' verbal creativity. The next stage is the decision making stage which means the decision making process to make and do something. Students then proceed to the demonstration stage of doing and making something to include, demonstrating the ability to develop modeling and then building the things that are gained from the virtual world. Students then do technical detail or check and collect data, as well as obstacles encountered with the object identified in writing. In the final stages of exploring the students are asked to build a relationship between the information obtained with relevant knowledge then actively participate in class discussions.

Herga \& Dinevski (2012) explains that virtual labs open up a whole new world of creativity in learning. This is in line with the opinion of Oidovet al. (2012) which states that the animation that is in the virtual lab can be used as an ideal demonstration tool to present an event. In accordance with the stages of virtual laboratory usage in the period of demonstrate, students can actively and creatively use the tool towards meaningful experimental results. The activity will have an impact on creativity in understanding the theoretical and practical aspects based on virtual experiments performed. Based on this, this study is intended to obtain the results of empirical testing on the effect of the application of virtual laboratory models on electrical materials that have been developed on the creativity of prospective physics teachers.

\section{METHOD}

This research has successfully developed a virtual laboratory model on electrical concept. This research consists of three stages, namely preliminary study stage, design development stage, and model testing stage. In the model testing phase, the method used is quasi experimental research. The sample of this research is physics teacher education student in Mataram which are divided into two groups, experiment and control. The experimental group is taught with virtual electric lab assisted learning, while the other group is a control group taught conventionally. Conventional learning uses direct instruction model. The study was conducted for 6 meetings. Each meeting is held for 2 x 50 minutes.

The research instrument used is a test of creativity in the form of essay test. The test consists of two parts: a verbal creativity test and a figural creativity test. The verbal creativity test related to the ability to compose words, sentences, and explanations that are relevant to the concept. The figural creativity test related to the ability to create an image, complete it, or create a series relevant to the electrical concept. The verbal and figural verbal creativity tests are related to electrical material that has been studied in both groups. Data were analyzed by using appropriate statistical tests using SPSS version 20 software aid.

Enhancement of student creativity is determined from normalized gain scores ( $\mathrm{N}$-gain). This is intended to avoid errors in the interpretation of individual gain scores. To obtain an $\mathrm{N}$-gain score, the following equations are used (Cheng et al., 2004).

$\mathrm{N}$ - gain $=\frac{\mathrm{S}_{\text {post }}-\mathrm{S}_{\text {pre }}}{\mathrm{S}_{\text {max }}-\mathrm{S}_{\text {pre }}} \times 100 \%$

Where $\mathrm{N}$-gain $>70 \%$ (high); $30 \% \leq \mathrm{N}$-gain $\leq$ $70 \%$ (moderate); and N-gain < 30\% (poor).

In this research, empirical testing stage has been done to find out the advantages of virtual lab model to develop creativity of physics teacher candidate. Figure 1 shows some examples of virtual experiments on electrical concepts that have been developed.

The virtual laboratories have been developed in the form of interactive simulations that can be used to conduct virtual physics experiments by students on the material being studied. There are a total of 41 virtual experiments developed in this study.

The virtual laboratories used have been validated in advance on aspects of physical content as well as on aspects of media and technology used. Some substantial improvements have been made to the refinement of the program before it is used in extensive trials for measuring the advantages of virtual lab models on the creativity of prospective physics teach- 
ers, both verbal and figural. In extensive trials students of physics teacher candidates are divided into two groups, namely experiment and control group.
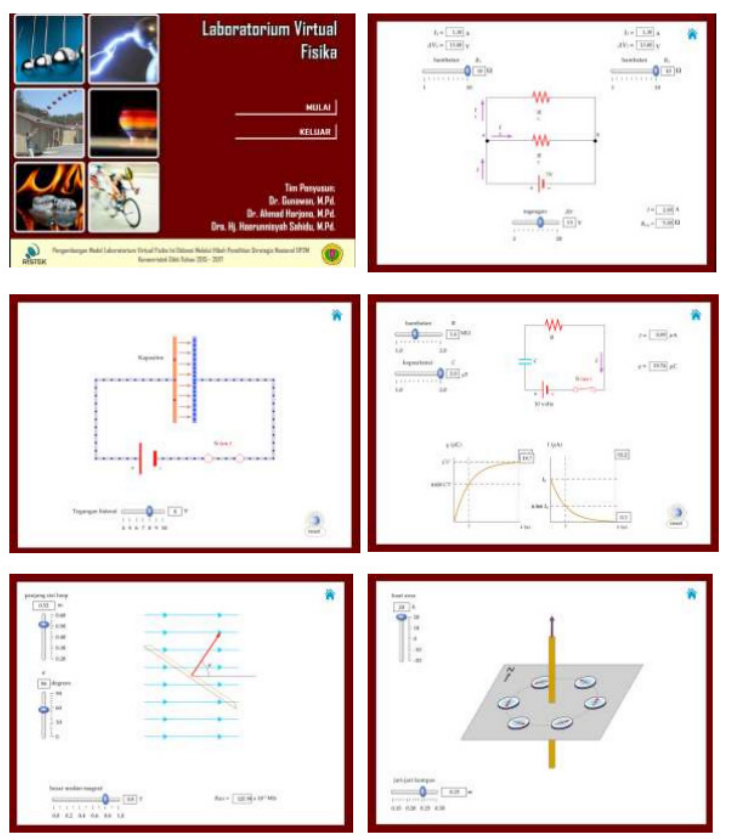

Figure 1. Some Examples of Electrical Virtual Laboratory

At the beginning of the program there is information about programs, research teams, and sponsors for program development. The next view is the program menu according to the material being studied. The program is focused on virtual experimentation activities so that physics material is not included in it. The design principles are adapted to the design principles and theories of multimedia cognitive, not too much text, as well as navigation systems associated with the subject structure that students are studying. Gunawan et al. (2016) revealed that this kind of design principle will help students to focus to understand what is shown in the program so that mastery of physics concepts learned to be better, especially students with visual learning style.

In its use, the student is allowed to use any textbook as long as it is related to the material being studied. Users are given the discretion to change a variable and see its influence directly to other variables. In this virtual laboratory assisted learning the students work independently by exploring the features freely for the achievement of learning objectives.

Setting these goals is important for the ease of measuring the success of creative learning. According to Shaheen (2010), the ed- ucational process needs to set goals, so that the creativity developed encourages that organized education has benefits to the community. Among the characteristics that must be trained on learners is learning how to do something creatively. Features and menus prepared in virtual labs allow participants the freedom to use their imaginations freely. Students are allowed to make plans and stages that they find easier to understand a concept. This virtual laboratory is accompanied by a student worksheet that contains a number of open questions and encourages students to respond with possible answers to a problem.

According to Horng et al. (2005), one of the goals of creative learning is the creation of a learning environment in which the imagination of learners is permitted and free from unnecessary regulations. Creative learning activities are centered on learner; there are multimedia aids, classroom management, material delivered in conjunction with real life, and open questions and encouragement for creative thinking.

The same opinion was expressed by Jackson (2006) which shows that creativity should involve students with questions and challenges; Create and see relationships; Consider what is possible; Explore ideas and options to stay open; And reflects a critical attitude to ideas, actions and outcomes. Toivanen et al. (2013) states that creativity always depends on the environment. Creativity does not occur in isolated or closed circumstances. Adams et al. (2007) stated that creativity is a skill that must be trained and equipped to students through the appropriate environment and using effective practice. This exercise should encourage creative thinking by having multiple divergent solutions. It is also recommended to use openended questions, where students must define what they need to solve the problem.

In virtual lab assisted learning, students learn not only physics using software but they can train many things including computer skills, scientific attitude, and cooperation. This is in accordance with the opinion of Black \& Browning (2011) which states that in digital art, students' understanding is also through the act of creating something as a form of self-expression, so they do not just learn new software. Zampetakis et al. (2007) also stressed that in an effort to train creativity, it should not only on the element of skills, but also attitudes, motivations, and self-image.

Virtual lab-assisted learning in the classroom can be divided into four stages in accor- 
dance with the time allocation, which is introduction, brainstorming, design, and share. At the introduction stage each student is introduced to the program and the learning objectives to be implemented. Students are given guidance and explanation of the function of each feature, menu, including test to be performed. This period should be made efficient, concise and clear. At the brainstorming stage each student identifies the experimental design criteria and constraints, writes the design plan, including identifying what data needs to be taken and compared. Brainstorming is the technique of individual or group creativity to find the conclusions of a particular problem by compiling a list of spontaneous ideas submitted by each member of his group. In the design phase students design and test the design of virtual experiments developed. Each data obtained is written on the worksheet. At the share stage, students present the experimental results and participate actively in class discussions.

\section{Students' Creativity after Learning}

In the learning of electrical concept in both groups, the data have been obtained related to the creativity of physics teacher candidates, either from the initial test, the final test, and the $\mathrm{N}$-gain. The following describes the results of the measurement of creativity after the electrical concept of learning. Figure 2 shows the average comparison of creativity test scores on initial, final, and $\mathrm{N}$-gain tests.

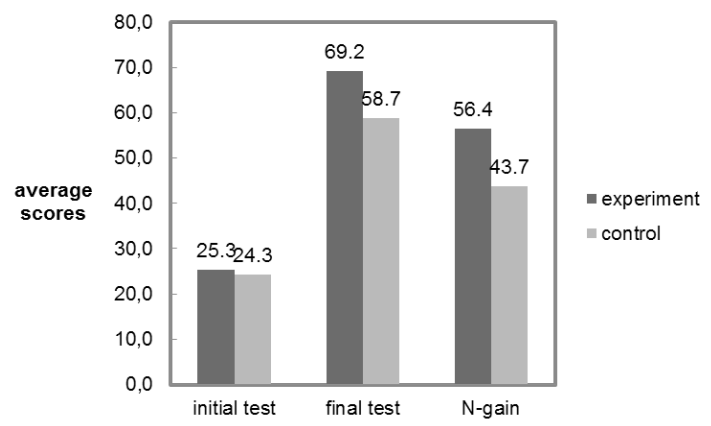

Figure 2. Comparison of Creativity Test Results of Both Groups

From Figure 2 it can be seen that the initial ability of the two groups is almost the same, indicating the average test results in both groups as well as the homogeneity test results that have been implemented. From the final test data and $\mathrm{N}$-gain can be obtained information on the increase in both groups. The increase is in the medium category. This enhancement of creativity is a positive influence of the virtual lab that has been developed. Characteristics of programs that provide flexibility in choosing features and determining stages according to the concept learned encourage the creativity of each student. In this learning program, there is discussion between students and lecturers with students. There are also sessions when students reflect on the satisfaction of the discovery of important concepts learned. The program facilitated group co-operation at a particular session to discuss the results of its virtual experiment.

Garaigordobil (2006) stated that there is a relevant role of social and affective factors in the development of creativity. In particular, they underline the positive effects of shared play, communication, and emotional expression for the development of creativity. This is consistent with the results of Gunawan \& Liliasari (2012) study which found that experimental class study students supported by appropriate virtual experiments have greater open-mindedness than control-class students who only hear information without being able to prove the truth of the theory through experiment.

A virtual laboratory for some students is also considered a fun game, as they can try and learn to make predictions that are further proved themselves. Put simply, it helps reduce the difficulty and tension in physics learning that is generally felt by some students while studying physics. This is in line with the results of research Byron, Khazanchi \& Nazarian (2010) who found the influence of stress on creative performance more complex than ever. Although, it still needs to do further researches at the stage and under what conditions stress which affects creativity. Other research conducted by Garaigordobil (2006) also shows that creative-cooperative game-based intervention programs can foster an increase in verbal and figural creativity. The results of Jackson et al. (2012) revealed that playing video games predicts all the steps of creativity. Regardless of gender or race, video game playfulness is associated with greater creativity.

One experimental study found a causal link between playing video games with visualspatial skills in adults (Green \& Bavelier, 2007). Even with more stringent criteria, there is a correlation between playing video games with every significant and positive creativity measurement. Aqda et al. (2011) have identified factors that can enhance creativity, such as letting students experience without limiting them 
to specific situations, giving them opportunities for self-improvement and learning to discover, respect individual differences of learners, and provide models of creative behavior patterns to follow.

Some of the interactive experiments contained in the learning model provide a great opportunity for students to learn in estimating and to try their own to prove the truth of their estimates. The proven estimates that students have made can motivate students to learn more. If the student's estimates are not precise, the student can immediately predict the probable cause, and then correct it so that the final conclusion is made more precise. The task challenge and the experimental design project provided in the lessons also encourage student creativity. This is in line with the results of Suranti et al. (2016) who found that project assignments in virtual media-assisted learning models helped learners improve their ability to learn physics better than other conventionallylearned learners.

\section{Comparison of Verbal and Figural Creativity in Both Groups}

In addition to creativity data in general, this study also compares the improvement in every aspect of creativity after learning electrical concepts in both groups. A comparison of the improved verbal and figural aspects after learning in both groups is shown in Figure 3.

Based on Figure 3 it can be seen that the increase in verbal creativity is higher than the increase in figural creativity in both groups. Enhancement of creativity in both groups was in moderate category, except the increase of figural creativity in the control group which was still in the low category of $25.7 \%$. In a comprehensive analysis of the analytic factors of intellectual ability it can be found that the verbal ability is known to have a higher effect on the idea than the fluidity or flexibility. The results of this study are consistent with the results of O'Reilly et al. (2001) who found that the results of verbal creativity measurements were higher than figural in both groups, particularly on indicators of originality.

In Preckel et al. (2006) it is found a positive correlation between intelligence and creativity. The strongest correlation exists in verbal creativity. In his research Garaigordobil (2006) also found a significant positive influence of treatment in improving verbal and figural creativity. In this program verbal creativity is increased on three indicators, namely fluency, flexibility, and originality. Smoothness is related to the ability to generate many ideas; flexibility is concerned with proficiency in change from one approach to another or from a certain way of thinking to another; whereas originality is concerned with the capacity to bring new or more acceptable ideas or solutions.

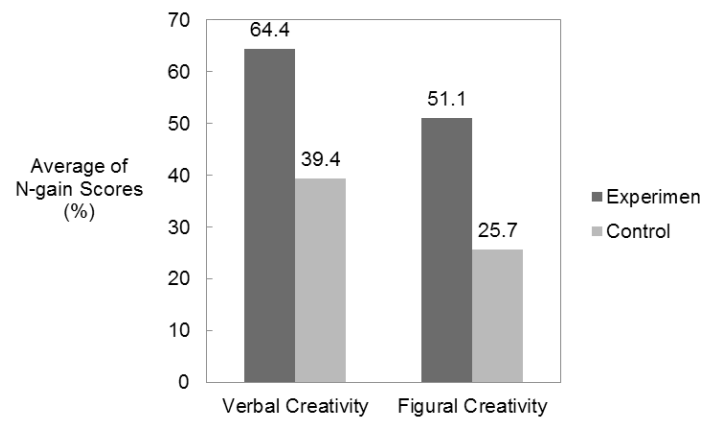

Figure 3. Comparison of Verbal and Figural Creativity in Both Groups

Although the increase of verbal creativity is higher than that of figural creativity, the difference in higher increase actually occurs in figural creativity. From the data obtained can be found there is $13.3 \%$ difference in verbal, $13.7 \%$ in figural. Increased verbal creativity in both groups was in the moderate category, whereas the improvement of creatural figural of the control group was in the low category. Cramond et al. (2005) found a very small correlation between verbal and figural creativity, whereas Wechsler (2006) states that verbal and figural creativity is significantly related. In creativity research that has been done, the correlation of verbal and figural creativity is highly dependent on the model of treatment accorded treatment as well as the type of instrument used for the measurement of any kind of creativity.

\section{Hypothesis Testing Results}

Prior to hypothesis testing, normality and homogeneity tests have been tested on creativity data of prospective physics teachers. Normality test results on creativity data that has been done shows that some data is normally distributed and some are not normally distributed. This then implies the type of hypothesis test used. Hypothesis test was performed by non-parametric statistic technique using MannWhitney test. Test conducted on creativity physics test data that includes the initial test, the final test, $\mathrm{N}$-gain verbal, figural and $\mathrm{N}$-gain total. Table 1 shows the hypothetical test results of creativity data. 
Table 1. Hypothesis Test Results of Creativity Data

\begin{tabular}{|c|c|c|}
\hline Mann-Whitney & Sig. & Interpretation \\
\hline $\begin{array}{l}\text { Total Scores } \\
\text { of Initial Test }\end{array}$ & .579 & $\begin{array}{l}\text { There was no initial } \\
\text { creativity difference } \\
\text { between the two sample } \\
\text { groups }\end{array}$ \\
\hline $\begin{array}{l}\text { Total Scores } \\
\text { of Final Test }\end{array}$ & .000 & $\begin{array}{l}\text { There is a final creativity } \\
\text { difference between the } \\
\text { two sample groups }\end{array}$ \\
\hline $\begin{array}{l}\mathrm{N} \text {-gain of ver- } \\
\text { bal creativity }\end{array}$ & .001 & $\begin{array}{l}\text { There is a difference in } \\
\mathrm{N} \text {-gain of verbal cre- } \\
\text { ativity between the two } \\
\text { sample groups }\end{array}$ \\
\hline $\begin{array}{l}\mathrm{N} \text {-gain of fig- } \\
\text { ural creativity }\end{array}$ & .018 & $\begin{array}{l}\text { There is a difference in } \\
\mathrm{N} \text {-gain of figural cre- } \\
\text { ativity between the two } \\
\text { sample groups }\end{array}$ \\
\hline $\mathrm{N}$-gain total & .000 & $\begin{array}{l}\text { There is a difference of } \\
\mathrm{N} \text {-gain creativity between } \\
\text { the two sample groups }\end{array}$ \\
\hline
\end{tabular}

From Table 1 data it can be seen that before the treatment the level of creativity of prospective teachers in the two groups is no different. This is reinforced by homogeneity test results that have been done previously indicating that the variance between the two groups is homogeneous. After treatment there was a significant increase in the experimental group. There is a difference of creativity increase, both verbal and figural creativity improvement in both groups significantly. From the results of statistical tests on this indicator obtained the conclusion of a significant difference in the increase of verbal and figural creativity between the two sample groups. Improvement in experiment group is higher than control group.

This significant difference is due to the learning by the laboratory that is carried out supporting the development of the creativity of prospective physics teachers. Among the favorable situations include: learning with a virtual laboratory brings openness, encourages questions, encourages generating something, responsibility and independence, emphasizes initiatives to classify data, estimate and test the estimates themselves, and communicate them to others.

The habituation of creative activities through virtual experiments as well as creative evaluations impacts the results of creativity measurements. This is relevant to the results of O'Reilly et al. (2001) which shows the comparison of two groups of creativity measurements from creative arts programs and literary programs. In the measurements on various indicators of creativity can be seen creativity of participants from creative arts groups higher than the literary group on all indicators tested. Cropley \& Cropley (2010) in his research shows that creativity is oriented to reality that involves knowledge and skills that can be trained. Williams (2002) views the issue of creativity assessment from a different perspective. In his research did not assess the product of creativity, but assessed the extent to which the task given was able to bring creativity in the first step.

Virtual lab-assisted learning is not only makes learning creative physics but is also used to train and equip the creativity of physicsminded teachers. According to Cremin (2006, 2009), the distinction between creative teaching and teaching for creativity tends to highlight the orientation of educators and the orientation of learners. Creative teaching involves educators in making learning more engaging and effective using imaginative approaches in the classroom. Teaching for creativity involves educators in identifying creative forces and encouraging learners' creativity.

Rawat et al. (2012) stated that a creative person is essentially a person who is able to form publicly accepted judgments in an unprecedented situation. A creative person achieves this goal through the ability to analyze the situation appropriately. Appropriate analysis causes him to be involved in the situation, and leads him to separate important and relevant facts capable of influencing the situation. A creative person, on the basis of this analysis can form an appropriate assessment of the situation and can create new solutions in an unprecedented or usual situation.

In their study Gunawan et al. (2013) have found that students who study with virtual labs have generic science skills higher than those conventionally studied. Learning with virtual labs improves the ability of logic inference and the ability to build physics concepts. The results of Siswanto et al. (2016) also found that physics learning using e-Lab is effective to improve students' generic science skills. Generic science skills have a positive effect on students' conceptual understanding on photoelectric effect, Compton Effect, and electron diffraction. Haseman \& Jaaniste (2008) summarizes the relationship between creativity and its benefits to the general public: creating the right atmosphere, building the skills needed in the future workforce, generating new knowledge, and en- 
couraging entrepreneurial activity.

\section{CONCLUSION}

Based on the results of research and discussion that has been submitted, it can be concluded that the virtual lab model on electrical materials that have been developed give a significant influence on the improvement of creativity of physics teacher candidates. Creativity in the experimental group experienced a higher increase than the control group. Increased verbal creativity is higher than figural creativity in both groups. There are significant differences in creativity improvement in both groups, both in general and from verbal and figural aspects. This shows that learning with virtual labs that have been done proven to increase the creativity of prospective physics teachers.

\section{ACKNOWLEDGMENT}

We would like to thank to the Directorate of Research and Community Service at the Ministry of Research, Technology and Higher Education who have funded this research through the National Strategic Research Grant Scheme 2015-2017.

\section{REFERENCES}

Adams, J. P., Kaczmarczyk, S., Picton, P., \& Demian, P. (2007). Improving problem solving and encouraging creativity in engineering undergraduates.development, 3,5 .

Aqda, M. F., Hamidi, F., \& Rahimi, M. (2011). The comparative effect of computer-aided instruction and traditional teaching on student's creativity in math classes. Procedia Computer Science, 3, 266-270.

Batey, M., \& Furnham, A. (2006). Creativity, intelligence, and personality: A critical review of the scattered literature. Genetic, Social \& General Psychology Monographs, 132(4), 355-429.

Black, J., \& Browning, K. (2011). Creativity in digital art education teaching practices. Art Education, 64(5), 19-34.

Bricken, M., \& Byrne, C. M. (1993). Summer Students in Virtual Reality. Virtual Reality: Applications and exploration, 199-218.

Byron, K., Khazanchi, S., \& Nazarian, D. (2010). The relationship between stressors and creativity: A meta-analysis examining competing theoretical models. Journal of Applied Psychology, 95(1), 201.

Chen, X., Song, G., \& Zhang, Y. (2010). Virtual and remote laboratory development: A review.
In Earth and Space 2010: Engineering, Science, Construction, and Operations in Challenging Environments (pp. 3843-3852).

Cheng, K. K., Thacker, B. A., Cardenas, R. L., \& Crouch, C. (2004). Using an online homework system enhances students' learning of physics concepts in an introductory physics course. American Journal of Physics, 72(11), 1447-1453.

Ciepiela, E., Harężlak, D., Kocot, J., Bartyński, T., Kasztelnik, M., Nowakowski, P \& Bubak, M. (2010). Exploratory programming in the virtual laboratory. In Computer Science and Information Technology (IMCSIT), Proceedings of the 2010 International Multiconference on (pp. 621-628). IEEE.

Cramond, B., Matthews-Morgan, J., Bandalos, D., \& Zuo, L. (2005). A report on the 40-year followup of the Torrance Tests of Creative Thinking: Alive and well in the new millennium. Gifted Child Quarterly, 49(4), 283-291.

Cremin, T (2006) Creativity, uncertainty and discomfort: teachers as writers. Cambridge Journal of Education, 36:3, 415-33.

Cremin, T. (2009). Creative teachers and creative teaching. Creativity in primary education, 3646.

Cropley, D., \& Cropley, A. (2010). Recognizing and fostering creativity in technological design education. International Journal of Technology and Design Education, 20(3), 345-358.

Garaigordobil, M. (2006). Intervention in creativity with children aged 10 and 11 years: Impact of a play program on verbal and graphic-figural creativity.Creativity Research Journal, 18(3), 329-345.

Green, C. S., \& Bavelier, D. (2007). Action video experience alters the spatial resolution of vision. Psychological Science, 18, 88-94.

Gunawan, G., \& Liliasari, L. (2012). Model Virtual Laboratory Fisika Modern untuk Meningkatkan Disposisi Berpikir Kritis Calon Guru. Jurnal Cakrawala Pendidikan, 5(2).

Gunawan, G., Harjono, A., \& Imran, I. (2016). Pengaruh Multimedia Interaktif dan Gaya Belajar Terhadap Penguasaan Konsep Kalor Siswa. Jurnal Pendidikan Fisika Indonesia, 12(2), 118-125.

Gunawan, G., Setiawan, A., \& Widyantoro, D. H. (2013). Model Virtual Laboratory Fisika Modern untuk Meningkatkan Keterampilan Generik Sains Calon Guru. Jurnal Pendidikan dan Pembelajaran (JPP), 20(1), 25-32.

Harding, T. (2010). Fostering creativity for leadership and leading change. Arts Education Policy Review, 111(2), 51-53

Harms, U. (2000). Virtual and Remote Labs in Physics Education. Paper presented at Second European Conference on Physics Teaching in Engineering Education, Budapest.

Haseman, B. C. \& Jaaniste, L. O. (2008). The arts and Australia's national innovation system 
(1994-2008). CHASS Occasional Paper, 7 7-39.

Herga, N. R., \& Dinevski, D. (2012, June). Using A Virtual Laboratory to Better Understand Chemistry-An Experimental Study on Acquiring Knowledge. In Information Technology Interfaces (ITI), Proceedings of the ITI 2012 34th International Conference on (pp. 237242). IEEE.

Horng, J. S., Hong, J. C., ChanLin, L. J., Chang, S. H., \& Chu, H. C. (2005). Creative teachers and creative teaching strategies. International Journal of Consumer Studies, 29(4), 352-358.

Jackson, L. A., Witt, E. A., Games, A. I., Fitzgerald, H. E., von Eye, A., \& Zhao, Y. (2012). Information technology use and creativity: Findings from the Children and Technology Project. Computers in human behavior, 28(2), 370-376.

Jackson, N. (2006). Creativity in higher education: What's the problem. Higher Education, 7.

Kandiko, C. B. (2012). Leadership and creativity in higher education: the role of interdisciplinarity. London Review of Education, 10(2), 191200.

Kusdiastuti, M., Harjono, A., Sahidu, H., \& Gunawan, G. (2016). Pengaruh Model Pembelajaran Inkuiri Berbantuan Laboratorium Virtual Terhadap Penguasaan Konsep Fisika Peserta Didik. Jurnal Pendidikan Fisika dan Teknologi, 2(3), 116-122.

Mishra, P. (2012). Rethinking technology \& creativity in the 21st century: Crayons are the future. TechTrends, 56(5), 13-16.

Mumford, M. D., Hunter, S. T., \& Byrne, C. L. (2009). What is the fundamental? The role of cognition in creativity and innovation. Industrial \& Organizational Psychology, 2(3), 353-356.

Nisrina, N., Gunawan, G., \& Harjono, A. (2016). Pembelajaran Kooperatif dengan Media Virtual untuk Peningkatan Penguasaan Konsep Fluida Statis Siswa. Jurnal Pendidikan Fisika dan Teknologi, 2(2), 66-72.

O'Reilly, T., Dunbar, R., \& Bentall, R. (2001). Schizotypy and creativity: an evolutionary connection?. Personality and Individual Differences, 31(7), 1067-1078.

Oidov, L., Tortogtokh, U., \& Purevdagva, E. (2012). Virtual Laboratory for Physics Teaching. In International Conference on Management and Education Innovatio, IPEDR Vol. 37, pp. 319-323.

Preckel, F., Holling, H., \& Wiese, M. (2006). Relationship of intelligence and creativity in gifted and non-gifted students: An investigation of threshold theory.Personality and individual differences, 40(1), 159-170.

Rawat, K. J., Qazi, W., \& Hamid, S. (2012). Creativity and education.Academic Research International, 2(2), 264.

Runco, M. A. (2004). Creativity. Annual Review of
Psychology, 55(1), 657-687

Sari, P. I., Gunawan, G., \& Harjono, A. (2016). Penggunaan Discovery Learning Berbantuan Laboratorium Virtual pada Penguasaan Konsep Fisika Siswa. Jurnal Pendidikan Fisika dan Teknologi, 2(4), 176-182.

Shaheen, R. (2010). Creativity and Education. Creative Education, 1, 166-169.

Siswanto, J., Saefan, J., Suparmi, S., \& Cari, C. (2016). The effectiveness of e-Lab to improve generic science skills and understanding the concept of physics. Jurnal Pendidikan Fisika Indonesia, 12(1), 33-40.

Sugiana, I. N., Harjono, A., Sahidu, H., \& Gunawan, G. (2016). Pengaruh Model Pembelajaran Generatif Berbantuan Media Laboratorium Virtual Terhadap Penguasaan Konsep Fisika Siswa pada Materi Momentum dan Impuls. Jurnal Pendidikan Fisika dan Teknologi, 2(2), 61-65.

Suranti, N. M. Y., Gunawan, G., \& Sahidu, H. (2016). Pengaruh Model Project Based Learning Berbantuan Media Virtual Terhadap Penguasaan Konsep Peserta didik pada Materi Alat-alat Optik. Jurnal Pendidikan Fisika dan Teknologi, 2(2), 73-79.

Toivanen, T., Halkilahti, L., \& Ruismäki, H. (2013). Creative pedagogy-Supporting children's creativity through drama. The European Journal of Social \& Behavioural Sciences, 7(4), 1168-1179.

Wechsler, S. (2006). Validity of the Torrance Tests of Creative Thinking to the Brazilian culture. Creativity research journal, 18(1), 1525.

Williams, G. (2002). Identifying tasks that promote creative thinking in mathematics: a tool. Mathematics education in the South $\mathrm{Pa}$ cific, 2, 698-705.

Wiyanto. (2008). Menyiapkan Guru Sains Mengembangkan Kompetensi Laboratorium. Semarang: Universitas Negeri Semarang Press.

Wu, H. Y., Wu, H. S., Chen, I. S., \& Chen, H. C. (2014). Exploring the critical influential factors of creativity for college students: A multiple criteria decision-making approach. Thinking Skills and Creativity, 11, 1-21.

Wyse, D., \& Ferrari, A. (2015). Creativity and education: Comparing the national curricula of the states of the European Union and the United Kingdom. British Educational Research Journal, 41(1), 30-47.

Zampetakis, L. A., Tsironis, L., \& Moustakis, V. (2007). Creativity development in engineering education: The case of mind mapping. Journal of Management Development, 26(4), 370-380.

Zimmerman, E. (2009). Reconceptualizing the role of creativity in art education theory and practice. Studies in Art Education, 50(4), 382-399.

Zimmerman, E. (2010). Creativity and art education: A personal journey in four acts. Art Education, 63(5), 84-92. 